\title{
フエ阮朝木造建築におけるドゥイ・ケオ絵様について A STUDY ON THE DUOI KEO DESIGH OF WOODEN ARCHITECTURES IN THE NGUEN DYNASTY AT HUE
}

\author{
白井裕泰*, 六反田千恵**, 中川 武*** \\ Hiroyasu SHIRAI, Chie ROKUTANNDA and Takeshi NAKAGAWA
}

\begin{abstract}
In order to clear the transition of design style, we have studied on the Duoi Keo design of wooden architectures in The Nguen Dynasty at Hue. The conclusion of this paper is as follows. : 1. To clarify the production age of the Duoi Keo design of wooden architectures, we have cleared the creation age and detailed repair of 34 wooden architectures in existence by the document and hearing. 2. We have classified the Duoi Keo design of wooden architectures to four types, A type is “両渦文型”, B type is “龍頭吐水唐草文型”, C type is “小龍頭渦唐草文型 “, D type is “渦唐草文 型”. 3. The transition of the Duoi Keo design is as follows. A-type $\rightarrow$ B-type $\rightarrow C$-type and D-type. 4 . We have presumed the new construction age of the wooden architectures in existence, that is that Dien Tho Ninh was built in 1820, the upstairs of Ngo Mon was built in 1921-23, and Hung Mieu was built in the middle of 19 century.
\end{abstract}

Keywords : The Duoi Keo design, wooden architectures, The Nguyen Dynasty, Hue, Vietnam ドウイ・ケオ絵様，木造建築，阮朝，フエ，ヴィエトナム

\section{1. はじめに}

ヴィエトナム・フエにおける阮朝木造建築は、1993 年ユネスコ世 界遺産に登録された「フエの建造物群」の主要な構成要素である。 これまで早稲田大学中川武研究室は、1996 年以来、京城、帝陵に現 存する木造建築遺構群に関寸る調查を実施し、配置計画研究、寸法 計画研究、細部意匠研究、文献研究など様々な視点から遺構群の分 析を通して研究成果を発表してきた。

本論文では、細部意匠研究の 1 つとして登梁木鼻 (ドゥイ・ケオ 絵様について考察を行う。フエにおける阮朝木造建築の遺構群は、 創建以来、幾度も修理が行われ、また再建されたものもある。その 経緯に関して、文献研究だけでは明らかにすることができず、建築 史的見地から、遺構の建立年代を確定する必要がある。本論文では、 細部意匠の様式変遷を考察することによって、建立年代を確定する という方法論を前提に、ドゥイ・ケオ絵様の変遷について考察を試 みるものである。

現存する遺構群に関するこれまでの調査によって、各遺構にはそ の時々の破損状況に応じて、解体修理、半解体修理、屋根替修理、 部分修理（塗装修理を含む）などの修理が繰り返し行われてきたこ とがわかっている。したがって現存遺構と創建建物の状況が異なっ ている可能性が極めて高く、同一遺構内に当初材と後補材が混在し ていると考えられる注1)。

しかしながら、阮朝木造建築群の主体となる遺構の基本的な架構 形式は、一部の例外はある注2) が、基本的には創建当初の形式を踏
襲していると考えられる。 現存遺構の創建年代および修理については、『欽定大南会典事例』 （1851）、『大南定録』（1844-1910）、『大南一統志』（1909）などの 文献史料から、建立年代および修理経緯はある程度把握することが できるが、完全なる把握は困難であるといえよう。

\section{2. 研究方法}

本研究では、阮朝木造建築遺構を対象として取り上げ、その細部 意匠の様式的変遷を明らかにする。細部意匠の中で、ドゥイ・ケオ に注目し、その拓本資料を作成し、現存する遺構におけるドゥイ・ ケオの絵様情報を整理し、絵様の分類を行う注3)。次に、阮朝木造 建築の創建年代および修理に関する情報を、前記三文献から抽出し、 整理する主4)。さらに現存遺構におけるドゥイ・ケオ絵様が、創建 当時の様式をもっていると仮定し、分類された絵様の変遷を明らか にする。ここで現存遺構におけるドゥイ・ケオ絵様が創建当時の様 式をもっているという仮定が成立するかどうかを明らかにする必要 があるが、知見できる範囲内であるが、これまでの修理を見ると、 ケオを取り替えるとき、旧ケオ両面のドゥイ・ケオ絵様を剥ぎ取っ て新材に張り付けたり、旧ドゥイ・ケオ絵様に倣って新ドゥイ・ケ 才絵様を彫刻していることから、この方法が従来の修理においても 踏襲されてきた可能性が高く、この仮定が成立すると考えることが できる。

\footnotetext{
* ものつくり大学技能工芸学部建設学科 教授. 工博

Prof., Dept. of Building Technologists, Faculty of Technologists, Institute of Technologists, Dr.Eng.

** 長谷川逸子・建築計画工房 所員 · 博士 (建築学)

Staff, Itsuko HASEGAWA Atelier, Dr.Arch.

*** 博物館明治村 館長, 早稲田大学 名誉教授・博士 (工学)

Prof. emeritus, Waseda University, Director, Open Air Museum Meiji-Mura, Dr.Eng.
} 


\section{3. 先行研究}

ヴィエトナム・フエにおける阮朝木造建築の細部意匠については、

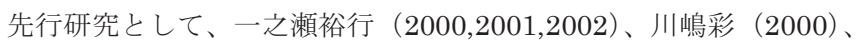
六反田千恵 $(2000-02,2006-10,2012 \cdot 13)$ などの論文があり注5)、こ れらの先行研究を踏まえて、六反田は早稲田大学博士論文『フエ・ 阮朝建築遺構群の細部意匠研究』(2014 年 2 月) をまとめた。

\section{3-1 前期 (2000-2002) の細部意匠研究}

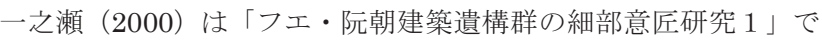
研究方法と問題を整理し、川嶋（2000）は「フエ・阮朝建築遺構群

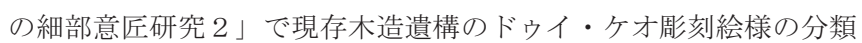
を行った。これらの研究が本論文のベースになっている。

川嶋（2000）は、対象としたドゥイ・ケオ絵様を次の 5 種（ただ しここでは絵様のない無地型を除いている）に分類した。

(1)渦紋型：立体的な元渦、中央に両渦紋を配するもの。また柱元下 方に渦紋を設け、外形をこれに合わせた繰型とする。先端にも渦 紋を施す。その他に渦紋を基調として若葉を付加する意匠を施す が、その形状は一定しない。

遺構例 : 左庶、右庶、太和殿、隆徳殿、肇祖廟、世祖廟、土公祀、

顕臨閣、興祖廟（左右裳階）、寿寧殿、北關台（方屋）、明 成殿

(2)渦龍型：立体的な元渦、中央に先端を向く龍頭を配するもの。龍 頭は頭髪、鼻、睲など具体的な形状を持つ。その他は(1)と共通す る。

遺構例：興祖廟（前裳階）、五鳳楼（下層）、明命帝陵崇恩殿・顕 徳門 (初層) - 碑亭・明楼 (初層)、紹治帝陵表徳殿・鴻澤 門・碑亭注 6

(3)唐草型 : 元渦を用いず、唐草紋を主体とするもの。柱元下方の繰 型、先端渦紋は(1) と類似する。

遺構例 : 長愉榭、隆安殿、明徽閣 (国子監)、明命帝陵明楼 (上層) 顕徳門（上層）、太平御覧書楼（上層）、同慶帝陵凝禧殿 後殿・宮門

(4)龍唐草型 : (3)と類似するが、中央に柱元を向く小龍頭を配するも の。瞳、鼻など具象的な形状を持つが、(2)の龍頭とは形状が異な る。

遺構例 : 太平御覧書楼 (初層)、延寿宮正殿、嗣徳帝陵和謙殿・良 謙殿・謙宮門・鳴謙堂・愈謙榭・冲謙榭、建福帝陵執謙 堂、育徳帝陵隆恩殿、同慶帝陵凝禧殿前殿

(5)龍雷型 : 柱元方を向く小龍頭を直線的な雷紋、唐草紋を組み合わ せるもの。小龍頭は(4)と類似する。

遺構例：五鳳楼（上層）

また川嶋は文献史料による遺構の創建年代を根拠として、5 分類 の成立時期を以下のように整理した。

(1)渦紋型：嘉隆元（1842）から明命年間（1820-40）初頭、寸なわ ち 19 世紀初頭の創建遺構のほとんどがこの型に属する。ただし 王宮内の延寿宮寿寧殿のみが嗣徳 (1847-83) 初年創建と遅れる。

(2)渦龍型：この型に属するものは、総て明命年間初頭から紹治年間 （1841-47）を経て、嗣徳年間初頭の 19 世紀中期の創建遺構であ る。

(3)唐草型 : 早いもので明命年間、遅いもので成泰年間 (1889-1907) 初頭の比較的長い期間（19 世紀前半〜末期）に分散する。
(4)龍唐草型 : 嗣徳年間初頭から成泰年間初頭の 19 世紀後半の創建 遺構に限られる。

(5)龍雷型 : 明命 14（1833）創建の五鳳楼上層のみに見られる。 このように 19 世紀初頭に(1)渦紋型、19 世紀中期に(2)渦龍型、19 世紀中期〜末期に(3)唐草型および(4)龍唐草型が用いられたと考えら れる。(5)龍雷型は明命期のものであるが、啓定帝陵遺構や紫禁城の 仁聲八表殿など啓定年間（1916-25）の創建になる遺構に類似した 意匠が見られることから、王朝末期（20 世紀前半）の意匠である可 能性が高いと指摘している注7)。

また六反田 (2000) は「フエ・阮朝建築遺構群の細部意匠研究 $3 」$ で五鳳楼初層のドゥイ・ケオ彫刻絵様の分類を行い、ドゥイ・ケオ に施された彫刻意匠が多様性を持っていることを指摘した。他の遺 構におけるドゥイ・ケオ絵様が遺構内において同一性を持っている ことから、五鳳楼のドゥイ・ケオ絵様の特異性を明らかにした注8)。 さらに一之瀬 (2001) は「フエ・阮朝建築遺構群の細部意匠研究 5 」 で肇祖廟における木部彫刻部位の特徵を明らかにし、六反田 (2001) は「フエ・阮朝建築遺構群の細部意匠研究 $6 」$ でドゥイ・ケオ絵様 の部分である元渦紋 (頭部渦文) 形状を分類した。また一之瀬 (2002) は「フエ・阮朝建築遺構群の細部意匠研究 $7 」$ ‘゙ケオの形状と彫刻 について分析し、5つのタイプに分類し、ケオ彫刻がより多くの人 が通り、より人の目に触れる部位に多くの彫刻を施すという傾向を 指摘し、架構部位によってその彫刻形式が使い分けられ、彫刻によ って遺構の格式を表現していることを明らかにした。六反田 (2002) は「フエ・阮朝建築遺構群の細部意匠研究 $8 」$ で大梁木鼻（ダウ・ チェン）の意匠形態による分析を行い、タイプ 1 (線刻／浮彫)、タ イプ 2、タイプ 3 (線刻／浮彫)、タイプ 4 の計 6 種に分類した。

タイプ 1 : 後方(柱元)上部から下向きの曲線の先端に上向きの渦 紋が取り付き、上向き渦紋の後方若葉を持つもの。

タイプ 2 : 後方上部からの下向きの渦紋と前方上部からの下向き の渦紋が交差するもの。

タイプ 3 : 前方上部からの下向き渦紋とこれに付随する若葉や小 渦、葉紋などで構成される。

タイプ 4 : 後方上部から渦紋と前方上部からの渦紋が接し、これ に付随する若葉、小渦、葉紋などがみられる。

\section{3-2 後期 (2006-2014) の細部意匠研究}

前期の細部意匠研究以後、六反田は 2006-12 にかけて継続的に細 部意匠研究を行い、それまでの研究成果を踏まえて、早稲田大学博 士論文『フエ・阮朝建築遺構群の細部意匠に関寸る研究』(2014 年 2 月）をまとめた。この論文において特に注目される点は、第 1 に 阮朝建築遺構群の造営過程を文献史料およびフエ遺跡保存センター

(以下 HMCC と略寸) からのヒアリングによって明らかにしたこ と、第 2 に重梁の彫刻絵様構成を分類し、その変遷を明らかにした ことである。

以上の先行研究を踏まえて、本論文ではドゥイ・ケオ絵様の変遷 過程を再考し、様式編年を明らかにする。

\section{4. 現存遺構の創建年代と修理経緯}

阮朝木造建築遺構におけるドウイ・ケオ絵様の制作年代を明らか にするため、現存遺構の創建年代と修理経緯を漢喃史料である『大 南定録』『钦定大南會典事例』『大南一統志』の三文献史料により明 
表 1 フエ阮朝木造建築遺構の創建年代と修理経緯

\begin{tabular}{|c|c|c|c|c|c|c|c|c|c|c|}
\hline 場所 & 区域 & \begin{tabular}{|l|l|} 
NNo. 遺構 \\
\end{tabular} & 創建年代 & 修理1 & 修理2 & 修理3 & 修理4 & 戦後修理1 & 輠後修理2 & 備考 \\
\hline \multirow{16}{*}{ 皇城 } & \multirow[b]{2}{*}{ 外朝 } & 1 五鳳楼 & 嘉隆5.1806[事](乾元殿) & 明命12·1831【事】(乾元殿) & 改建: 明命14·1833【事·定·統】 & 成泰年間·1889-1907 & $1921-23$ & $1990-92$ & 1999 (屋根) & 2013から解体修理 \\
\hline & & \begin{tabular}{l|l}
2 & 太和殿 \\
\end{tabular} & 嘉隆4·1805【定】 & 嘉隆18·1819【定】 & \begin{tabular}{|l} 
移箖: 明命13-14·1832-33 \\
[事·家·統]
\end{tabular} & 成泰3·1901【統】 & 啓定8-1923[扁】 & 1958 (屋根) & 1976-93 & 1960-1992にに小規模修理 \\
\hline & \multirow[b]{2}{*}{ 太廟 } & 3 隆德殿 & 嘉隆3·1804[統] & 明命13·1832(屋根)【事·統】 & $\begin{array}{l}\text { 成泰 } 12 \cdot 1900[\text { 統】 } \\
\end{array}$ & & & 2005-2010(ものつ & 穴り大解体) & \\
\hline & & 4 锺祖廟 & 嘉隆3·1804[定·統】 & 嘉隆13·1814[定] & 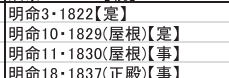 & 紹治2-3·1842-43(屋根)【事】 & & \begin{tabular}{|l|l}
$1982-83$ \\
1990
\end{tabular} & & 2013から解体修理 \\
\hline & \multirow{4}{*}{ 世廟 } & 5 顕臨閣 & 明命2-3·1821-22【定】 & 明命18.1837【事】 & & & & $1983-84 \cdot 1986$ & 1996-98(解体) & \\
\hline & & 6 世祖廟 & $\begin{array}{l}\text { 明命 } 2-3 \cdot 1821-22 \text { [定】 } \\
\text { 解 } 2 \cdot 1821 \text { [事·・統】 }\end{array}$ & 明命4-5.1823-24[定】 & 明命10·1829(屋根)【定·事】 & \begin{tabular}{|l} 
明命 $18 \cdot 1837$ (事) \\
明命 $20 \cdot 1839$ 屋根·塗装)[事]
\end{tabular} & & $1985 \cdot 1989 \cdot 1990$ & $\begin{array}{l}1996-98 \text { (解体) } \\
2003 \text { (整装) }\end{array}$ & \\
\hline & & \begin{tabular}{l|l}
7 土公祀 \\
\end{tabular} & 明命2·1821【統】 & 紹治2·1842(屋根)【事】 & & & & 2002(解体) & & \\
\hline & & 8 粤祖廟 & 嘉隆3·1804[定](皇考廟) & 嘉隆 11 -1812【定】(皇考廟) & 移建: : 明命2-1821【定·統】 & 紹治2・1842(屋根)【事】 & 嗣德31·1877【定】 & 移建: 1951( 現遺構 & & 1947焼失 \\
\hline & \multirow{4}{*}{ 紫禁城 } & & & 明命 $12 \cdot 1831$ [宣] & 明命10.1829(屋根)【定】 & 嗣德 $9 \cdot 1855$ 【定】 & & 1981 & 1995-97(解体) & 現遺構の建築年代は不明 \\
\hline & & 9 右庶 & 嘉隆18·1819【事】 & 明命11-12:1830-31【事】 & & & & 1986 & & \\
\hline & & 10 左䳸 & 嘉隆18·1819【事】 & $\begin{array}{l}\text { 明命 } 12 \cdot 1831 \text { 【定】 } \\
\text { 明命 } 12-12 \cdot 1830-3 \text { 事】 }\end{array}$ & & & & 1986 & & \\
\hline & & 11 态平御覧 & \begin{tabular}{|l|} 
同慶2-3・1886-87【定】 \\
同慶初にに改構【統】
\end{tabular} & & & & & $1987 \cdot 1989-91$ & 2011-13(半解体) & \\
\hline & \multirow{4}{*}{ 延寿宮 } & ${ }_{12}$ 延寿宮正 & 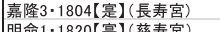 & 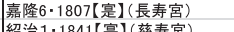 & 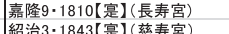 & & & & & \\
\hline & & 12 殿 & 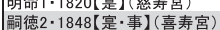 & 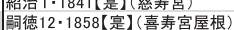 & 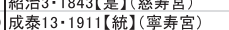 & 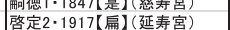 & & $1967 \cdot 1972 \cdot 1983$ & |1997-99(半解体) & |敋定1·1916延寿宮に改名 \\
\hline & & \begin{tabular}{l|l}
13 & 長㡏榭 \\
\end{tabular} & 嗣德2 2 -1848【事】 & 呞德3.1849[事] & & & & 1999-2000(解体) & 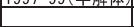 & 1927涼風亭を增築 \\
\hline & & 14寿賞殿 & 嗣德 $2 \cdot 1848$ [事] & 饲德 $3 \cdot 1849$ [事](建具) & & & & & & \\
\hline \multirow{3}{*}{ 京城 } & \multirow{3}{*}{ 皇城外 } & 15 隆安殿 & 紹治5·1845[定·統】(保定宮) & 解德 $34 \cdot 1880$ [定】(屋根) & 移築: 維新2·1908(新書館) & 慜定8·1923啓定美術館に改名 & & $\begin{array}{l}1972 \cdot 1984 \\
1994-95\end{array}$ & 2008-11(解体) & $\begin{array}{l}\text { 1947蔵古院に改名 } \\
\text { 1958フエ㙛館に二改名 }\end{array}$ \\
\hline & & 16 無倫堂 & 明命 $1 \cdot 1820$ 【事】 & 明命10·1829【扁】 & & & & & & \\
\hline & & 16 奛徽閣 & 紹治5·1845【扁】 & & & & & 2000 & & 維新2·1908[扁]改製 \\
\hline \multirow{18}{*}{ 皇帝陵 } & 嘉隆帝陵 & $\mid 17$ 明成殿 & \begin{tabular}{|l} 
嘉隆13.1814[寔·事] \\
隆14.1815[統]
\end{tabular} & \begin{tabular}{|l|} 
明命 $8 \cdot 1827$ [定】 \\
明命 $12 \cdot 1831$ [萣] \\
明命 $20 \cdot 1839$ [是】
\end{tabular} & 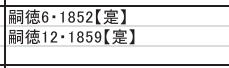 & 敌定7·1922【扁】 & & 1992-95正殿新笑 & 2001(湮装) & \\
\hline & \multirow{4}{*}{ 明命帝陵 } & 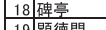 & 紹治1·1841【定·事】 & 糿治自 & & & & 2003-04(屋根・乷装 & 装) & \\
\hline & & 19 顥德門 & 紹治1·1841【定·扁】 & 紹治6・1846【【㔬】 & & & & & & \\
\hline & & 20 崇恩殿 & $\begin{array}{l}\text { 明命 } 21 \cdot 1840 \text { [事·統】 } \\
\text { 紹治1 } 1 \cdot 1841 \text { [事】 }\end{array}$ & 紹治6・1846[事】 & 嗣德12・1859[定】 & 同慶2·1886[定】 & & 1999-2000(解体) & & \\
\hline & & 21 明楼 & 紹治1·1841[定·事] & & & & & $1997-2000$ & & \\
\hline & \multirow{3}{*}{ 紹治帝陵 } & 22 碑亭 & 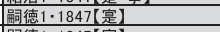 & & & & & $1990-2000$ & & \\
\hline & & 23 䲨澤門 & 嗣德 $1 \cdot 1847$ [是】 & & & & & & & \\
\hline & & 24 表德殿 & 嗣德1·1847[定·事·統】 & 骷德9·1855[定】(屋根) & 嗣德12·1859【定】 & & & 2006-10(解体) & & \\
\hline & \multirow{6}{*}{ 嗣徳帝陵 } & 25 愈謙榭 & 嗣德20・1866[定] & & & & & $1985 \cdot 1988$ & & \\
\hline & & 26 冲謙榭 & 哃德17·1863【扁】 & & & & & 1985 & & \\
\hline & & 27 謙宮門 & 嗣德20·1866[定] & & & & & & & \\
\hline & & 28 和謙殿 & 嗣德17·1863【届】 & 辟德19·1865【定】(屋根) & & & & 1990年代 & & 嗣德30-1876【定】謙宮成 \\
\hline & & 29 鳴謙殿 & 解德17-1863[扁] & & & & & & & 左従院 \\
\hline & & 30 良謙殿 & 嗣德17·1863【扁】 & & & & & & & \\
\hline & 建福帝陵 & 31 執謙殿 & 㖇德20.1866【定】 & 建福1·1883【續·扁】 & & & & $1997-98$ & & \\
\hline & 妾德帝陵 & 32隆思思殿 & 成泰 $2 \cdot 1900$ (統) & 成泰 $11 \cdot 1909$ [扁】 & & & & 1956 & 1998 & \\
\hline & \multirow[b]{2}{*}{ 同慶帝陵 } & 33 宮門 & 成泰1·1899[纘了(思陵) & & & & & $2011-2013$ & & \\
\hline & & 34 凝罟殿 & 同慶3·1887[扁】 & 成泰 $1 \cdot 1899$ [定】 & 啓定6.1913 & 敬定8·1923【扁】 & & $\begin{array}{l}1959 \cdot 1986 \cdot 1990 \cdot 1 \\
2012-2013(\text { 解体) }\end{array}$ & 1993 & \\
\hline
\end{tabular}

らかにする。これをまとめたものが表 1 である注 9)。

ただし現状太祖廟は、1947 年に焼失し、それ以後に再建されたも のであることから、現存遺構群から除外する。同様に清明楼は 1998-2000 年に再建されたことが判明しているので除外する。さら にドゥイ・ケオ絵様のない遺構も除外する。したがってここで対象 とする遺構は、京城・皇城内の五鳳楼、太和殿、隆徳殿、肇祖廟、 顕臨閣、世祖廟、土公祀、興祖廟、右廡、左廡、太平御覧書楼、延 寿宮正殿、長愉榭、寿寧殿、京城・皇城外の隆安殿、明徽閣、皇帝 陵の嘉隆帝陵明成殿、明命帝陵碑亭 - 顕徳門 - 崇恩殿 - 明楼、紹治 帝陵碑亭 - 鴻澤門 - 表徳殿、嗣徳帝陵愈謙榭 - 沖謙榭 - 謙宮門 - 和 謙殿・鳴謙堂・良謙殿、建福帝陵執謙殿、育徳帝陵隆恩殿、同慶帝 陵宮門・凝禧殿であり、現存する阮朝木造建築遺構 63 棟のうち、 京城・皇城内 14 棟、京城 - 皇城外 2 棟、皇帝陵 18 棟の合計 34 棟 である。

現存遺構の建立年代を、文献史料および HMCC からのヒアリン グをもとに推定すると、表 1 において着色した闌の年代になる。

\section{5. ドゥイ・ケオ絵様の分類}

\section{5-1 ケオ木鼻の部位名称}

川嶋（2000）は、ケオ木鼻の部位名称として「先端、中央、柱元、 柱元下」を用いているが、ここでは「鼻先、顔、頭、顎」という名 称を用いる注 10)。また顔下の繰形を「口」と呼ぶことにする（図 2 参照)。

\section{5-2 絵様の種類}

川嶋(2000)は、ドゥイ・ケオ絵様を「(1)渦紋型、(2)渦龍型、(3)唐 草型、(4)龍唐草型、(5)龍雷型」と分類しているが、ここでは「A両
渦文型、B 龍頭吐水唐草文型、C小龍頭渦唐草文型、D 渦唐草文型」 の 4 つに分類した (図 4 参照)。この分類の名称は、主にケオ木鼻 の顔部の様式から名付けたものである。ドウイ・ケオ絵様の分類を 5 つから 4 つにしたのは、龍雷型を「C’ 小龍頭渦唐草雷文型」と呼 ぶことができ、遺構例としては五鳳楼上層のドゥイ・ケオ絵様に限定 され、「C小龍頭渦唐草文型」の変形と考えることができるので、C タイプに含めたからである (図 6 参照)。「両渦文型」は、すでに六 反田（2006）が「両渦紋型」と呼称している注11)。また五鳳楼初層 の「両渦文型」は、両渦文の一部が若葉化していることから「A， 変形両渦文型」とした。ところでAタイプの絵様を用いる遺構のう ち、嘉隆帝陵明成殿のみが帝陵内の建物であり、それ以外はすべて

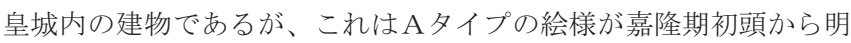
命期初頭に限定されて制作されたこと、明命帝陵以降の皇城外およ び帝陵内の建物が B・C・Dタイプの絵様を用いて紹治期以降に建 立されたことなどによるものと考えられる。

\section{6. ドゥイ・ケオ絵様の変遷}

表 1 のフエ阮朝木造建築遺構の建立年代を参考にして、ドウイ・ ケ才絵様の変遷をまとめたものが図 1-1・2 である。

Aタイプ: 両渦文型のドウイ・ケオ絵様は、嘉隆帝期初頭から明命帝 期（1804-1821）初頭に属し、唯一延寿宮寿寧殿のドゥイ・ケオ絵様 だけが嗣徳 2 年（1848）である。寿寧殿が延寿宮の前身である長寿 宮が建立された時期と同じであるとすれば、嘉隆 3 年（1804）に建 立された可能性がある注 12)。ところで明成殿重梁の彫刻絵様は、座 龍（龍が正面を向き、両足を踏ん張って座っている姿）が龍頭から 水を吐き（龍頭吐水）、龍頭下の両側に小龍頭が配置されている構図 


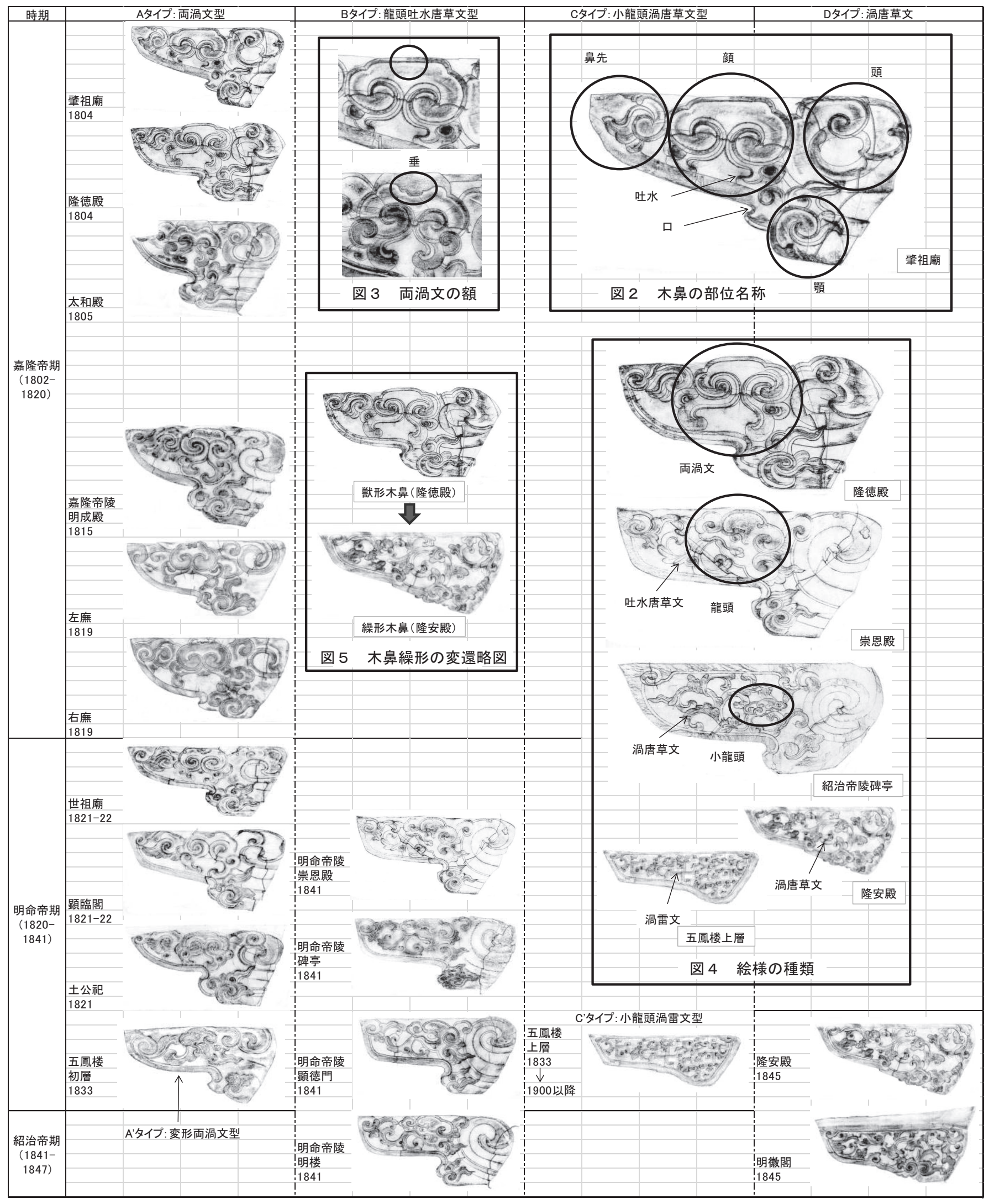

図 1-1 ドゥイ·ケオ絵様変遷図（1802-1847）（図 2・図 3・図4・図 5を含む）

となっていて、龍頭の額に両渦文がある。このことから推測すれば、 両渦文は座龍（図 7 参照）を象徴していると考えられる注 ${ }^{13)}$ 。

また両渦文の額（図 3 参照）をみると、嘉隆 3 年（1804）に建
立された肇祖廟・隆徳殿・寿寧殿には三葉の前髪がなく、嘉隆 4 年 (1805) 以降の太和殿をはじめとするすべての遺構に三葉の前髪が ついている。 


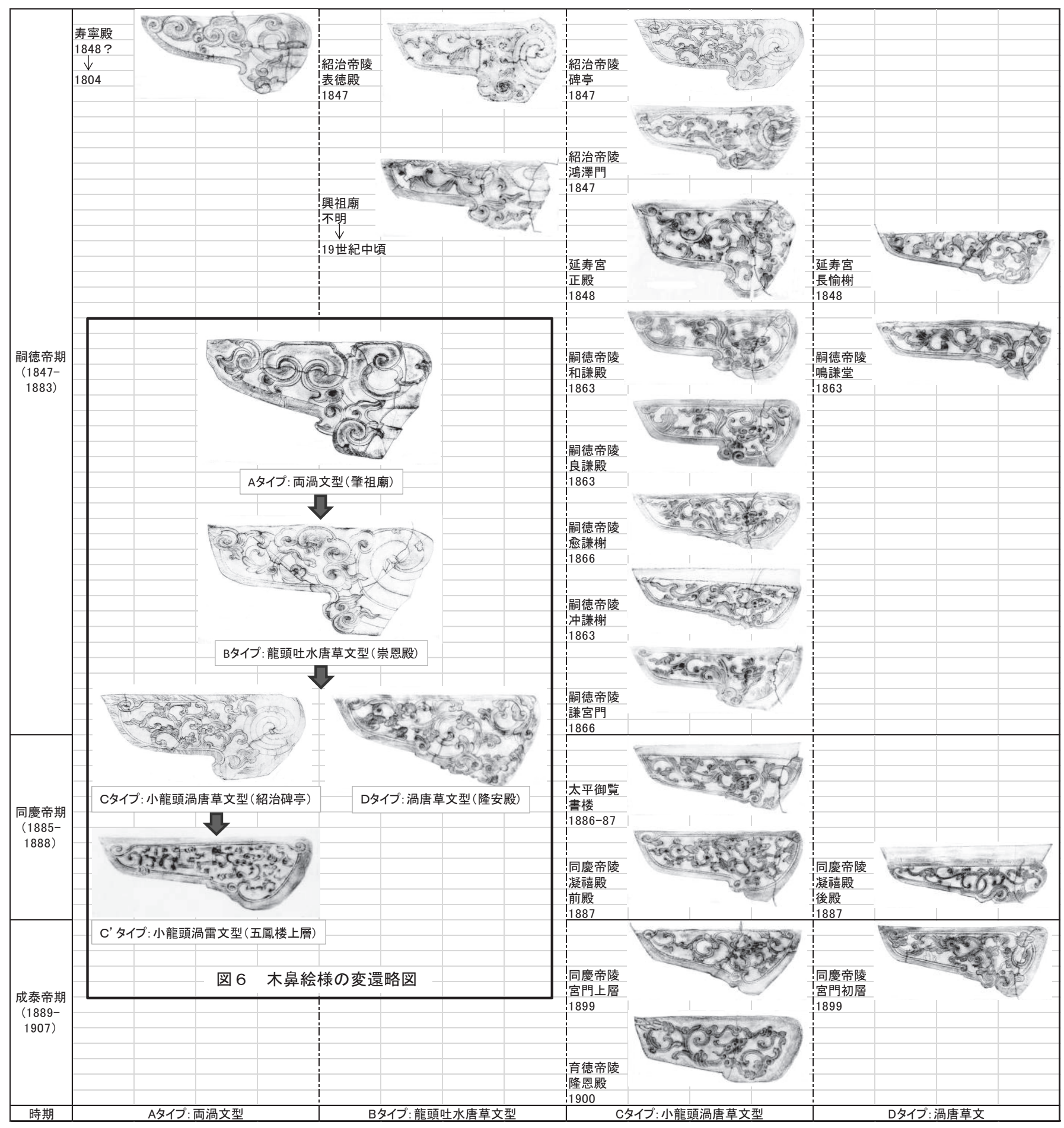

図 1-2 ドゥイ·ケオ絵様変遷図 (1847-1927)（図6 を含む）

B タイプ: 龍頭吐水唐草文型のドウイ・ケオ絵様は、紹治 1 年 (1841) に建立された明命帝陵崇恩殿・碑亭・顕徳門・明楼に用いられ、嗣 徳 1 年（1847）に建立された紹治帝陵の建物の中で表徳殿だけがこ のタイプの絵様を用いている。また興祖廟は 1951 年に移築したも のである注 ${ }^{14)}$ が、前身建物の建立年代は不明である。しかしドウイ・ ケオ絵様が B タイプであることから、建立年代は 19 世紀中ごろと 推定される。

Cタイプ: 小龍頭渦唐草文型のドゥイ・ケオ絵様は、嗣徳帝期から成 泰帝期にかけて（1847～1900）長く、かつ紹治帝陵碑亭・鴻澤門、
延寿宮正殿、嗣徳帝陵和謙殿・良謙殿・愈謙榭・冲謙榭・謙宮門（以 上嗣徳帝期）、太平御覧書楼、同慶帝陵凝禧殿（以上同慶帝期）、同 慶帝陵宮門上層、育徳帝陵隆恩殿（以上成泰帝期）など多くの建物 に用いられた。なおC' タイプ: 小龍頭渦唐草雷文型のドゥイ・ケオ 絵様は、五鳳楼上層にのみ見られることから、五鳳楼の再建年代で ある明命 14 年 (1833) のものではなく、1900 年以降のものと考え られる。

Dタイプ: 渦唐草文型のドゥイ・ケオ絵様は、Cタイプと同じ時期に 用いられたと考えられる。例えば嗣徳 2 年（1848）に建立された延 
寿宮正殿がCタイプ: 小龍頭渦唐草文型のドウイ・ケオ絵様、同時期 に建立された長愉榭が Dタイプ:渦唐草文型のドゥイ・ケオ絵様を用 いている。同様に、嗣徳 17 年（1863）に建立された嗣徳帝陵和謙 殿がCタイプ、同時期に建立された嗣徳帝陵鳴謙堂が D タイプを用 いている。また同慶 3 年（1887）に建立された同慶帝陵凝禧殿前殿 がCタイプ、同凝禧殿後殿注 ${ }^{15)}$ が Dタイプを用いている。さらに成 泰 11 年(1899)に建立された同慶帝陵宮門上層が C タイプ、宮門下層 が Dタイプを用いている。このことから、Cタイプのほうが Dタイ プより格式が高い空間に用いられる傾向がみられる注 ${ }^{16)} 。$

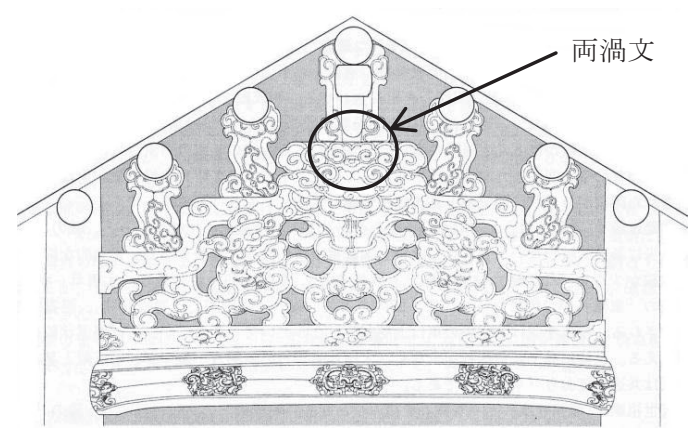

図 7 明成殿重梁注 $\left.{ }^{17}\right)$ (座龍を渦文で表現したもの)

以上の考察から、ドゥイ・ケオ絵様の変遷を概観すれば、Aタイ プ: 両渦文型 $\rightarrow \mathrm{B}$ タイプ : 龍頭吐水唐草文型 $\rightarrow \mathrm{C}$ タイプ : 小龍頭渦 唐草文型および $\mathrm{D}$ タイプ : 渦唐草文型 $\rightarrow \mathrm{C}$ ' タイプ : 小龍頭渦唐草 雷文型となる (図 6 参照)。

またドゥイ・ケオの繰形をみると、獣形木鼻から繰形木鼻へと変化 した (図 5 参照) と考えられる注 ${ }^{18)}$ 。繰形木鼻の初出は、紹治 5 年 (1845) に制作された隆安殿または明徽閣のドゥイ・ケオである注 19)。

\section{7. ドゥイ・ケオ絵様による建立年代の判定}

本論文では、文献史料および HMCC からの聞き取りをもとに、 現存する阮朝木造建築の建立年代を想定し、それに基づいてドゥ イ・ケオ絵様の変遷を明らかにした。その結果、いくつかの遺構の 建立年代に疑問が生じたので、ドゥイ・ケオ絵様の様式編年から判 断して、新たに遺構の建立年代を推定した。

7-1Ａタイプに属する遺構の建立年代

寿寧殿 : 寿寧殿の建立年代は、文献史料から嗣徳 2 年 (1848) と推 定されたが、そのドゥイ・ケオ絵様の特徵は、嘉隆初頭を下らない ことを示している。したがって寿寧殿は、延寿宮の初代目名称であ る長寿宮が建立された嘉隆 3 年（1804）と同時期に建立されたもの と考えられる。

五鳳楼：五鳳楼の建立年代は、文献史料から明命 14 年 (1833) と 推定されたが、主楼閣上層のドウイ・ケオ絵様の特徵は、成泰期以 降の特徵を示している。五鳳楼は嘉隆 5 年（1806）に創建され、明 命 14 年（1833）に再建され、成泰年間（1889-1907）および啓定 5-7 年（1921-23）に修理されたことが文献史料からわかっている。 また 20 世紀初頭に撮影された写真では、主楼閣だけを残して左右 の翼楼閣が破壊された状態が記録されている。さらに主楼閣上層部 分が台風によって大破したとも伝えられている。ユネスコ・ワーキ ンググループの報告書（1993 年）によると、啓定 5-7 年の修理が解
体修理であったことがわかっている注 ${ }^{20)}$ 。五鳳楼は、主楼閣初層の ドゥイ・ケオがタイプ B の絵様注 ${ }^{21)}$ を用い、一部にタイプ A’の絵 様（I5・I12）が用いられていることから判断して、明命 14 年の再 建時に創建建物の部材（タイプA'のドゥイ・ケオ）を一部に再用 して新築し、成泰年間に台風によって失われた翼楼閣を再建し、さ らに台風によって主楼閣を失ったので、啓定 5-7 年（1921-23）に 解体修理を行い、その際、主楼閣の上層に新しいC' タイプのドゥ イ・ケオ絵様を用いたと考えられる。

\section{7-2Ｂタイプに属する遺構の建立年代}

興祖廟: 興祖廟は、文献史料によると、嘉隆 3 年(1804)に皇考廟（前 身建物) が創建され、明命 2 年 (1821) に再建され、明命 10 年 (1829)、 紹治 2 年（1842）および嗣徳 31 年（1877）に屋根修理が行われ、 1947 年に戦火により焼失した。1951 年瑞輝皇后が金龍地区の離 宮・金龍社轉を興祖廟として移築した注 ${ }^{22)}$ が、金龍社轉の建立年代 は不明であった。しかし現遺構のドゥイ・ケオ絵様が、Bタイプの 特徴を示していることから、紹治期（19 世紀中ごろ）に建立された ものと考えられる。ところで金龍地区に延福長公主祀が現存するが、 この建物は、紹治帝が結婚する長女のために 1846 年に建てた住宅 である。離宮・金龍社轉は延福長公主祀と同時期に紹治帝によって 建立されたものかもしれない。

\section{7-3 C’タイプに属する遺構の建立年代}

五鳳楼：現在の五鳳楼は、前記したように、明命 14 年（1833）に 再建され、成泰年間（1889-1907）および啓定 5-7 年（1921-23）に 修理されたことが文献史料より明らかになっている。五鳳楼上層の ドゥイ・ケオ絵様は、20世紀初頭以降の特徴をしめしていることか ら、啓定 5-7 年（1921-23）の解体修理のとき新たに制作されたも のと考えられる。

\section{8. おわりに}

以上の考察をまとめると以下のようになる。

1 ）阮朝木造建築遺構におけるドゥイ・ケオ絵様の制作年代を明ら かにするため、現存遺構 34 棟の創建年代と修理経緯を漢喃史 料である『大南定録』『欽定大南會典事例』『大南一統志』の三 文献史料および HMCC からの聞き取りにより明らかにした。

2 ) 阮朝木造建築遺構におけるドゥイ・ケオ絵様の様式を「A両渦 文型、 $\mathrm{B}$ 龍頭吐水唐草文型、C小龍頭渦唐草文型、 $\mathrm{D}$ 渦唐草文 型」の 4 つに分類した。五鳳楼上層のドゥイ・ケオ絵様は、「C 小龍頭渦唐草文型」の変形と考え、「C' 小龍頭渦唐草雷文型」 とし、Cタイプに含めた。

3 ）ドゥイ・ケオ絵様の変遷を概観すれば、Aタイプ: 両渦文型 $\rightarrow$ $\mathrm{B}$ タイプ: 龍頭吐水唐草文型 $\rightarrow \mathrm{C}$ タイプ: 小龍頭渦唐草文型お よびDタイプ: 渦唐草文型 $\rightarrow C$ ' タイプ : 小龍頭渦唐草雷文型 となる。

4) ドゥイ・ケオ絵様の様式編年から判断して、新たに遺構の建立 年代を推定した結果、寿寧殿は嘉隆 3 年（1804）に、五鳳楼主 楼閣上層は啓定 5-7 年（1921-23）に、興祖廟は紹治期（19世 紀中ごろ）にそれぞれ建立されたと考えることができる。

なお本稿は、平成 $22-26$ 年度日本学術振興会科学研究費 (基盤研究 A）「阮朝・太廟・昭敬殿の復原計画一ヴィエトナムの文化遺産に関す 
る国際協力ー」(研究代表者・ものつくり大学教授白井裕泰) の成果の 一部である。このプロジェクトは、早稲田大学ユネスコ世界遺産研究所 (代表者・早稲田大学教授中川武) および省立フエ遺跡保存センター (代 表者・所長ファン・タン・ハイ）と共同で推進したものである。

\section{参考文献}

1）一之瀬裕行, 中川武, 西本真一, 中沢信一郎, 土屋武, 坂本忠規, 白井 裕泰, 六反田千恵, 高野恵子, 川嶋彩：フエ・阮朝建築遺構群の細部意 匠研究 1 - 研究方法と問題点, ヴィエトナム/フエ・阮朝王宮の復原的 研究, その 36, 日本建築学会大会学術講演梗概集, F-2, pp.287-288, 2000.9

2) 川嶋彩, 中川武, 西本真一, 中沢信一郎, 土屋武, 坂本忠規, 白井裕泰, 六反田千恵, 高野恵子, 一之瀬裕行 : フエ・阮朝建築遺構群の細部意匠 研究 2 ・現存木造遺構のドゥイ・ケオ彫刻絵様分類, ヴィエトナム/フエ・ 阮朝王宮の復原的研究, その 37 , 日本建築学会大会学術講演梗概集, F-2, pp.289-290, 2000.9

3) 六反田千恵, 中川武, 西本真一, 中沢信一郎, 土屋武, 坂本忠規, 白井 裕泰, 高野恵子, 川嶋彩, 一之瀬裕行: フエ・阮朝建築遺構群の細部意 匠研究 3 ・五鳳楼初層のドゥイ・ケオ彫刻絵様分類, ヴィエトナム／フエ・ 阮朝王宮の復原的研究, その 38 , 日本建築学会大会学術講演梗概集, F-2, pp.291-292, 2000.9

4）一之瀬裕行, 中川武, 西本真一, 中沢信一郎, 土屋武, 坂本忠規, 白井 裕泰, 六反田千恵, 高野恵子: フエ・阮朝建築遺構群の細部意匠研究 5 ・ 肇祖廟における木部彫刻部位とその特徵, ヴィエトナム/フエ・阮朝王 宮の復原的研究, その 46 , 日本建築学会大会学術講演梗概集, F-2, pp.171-172, 2001.9

5）六反田千恵, 中川武, 西本真一, 中沢信一郎, 土屋武, 坂本忠規, 白井 裕泰, 高野恵子: フエ・阮朝建築遺構群の細部意匠研究 6 - 元渦紋形状 の分類, ヴィエトナム/フエ・阮朝王宮の復原的研究, その 47 , 日本建 築学会大会学術講演梗概集, F-2, pp.173-174,2001.9

6) 一之瀬裕行, 中川武, 白井裕泰, 中沢信一郎, 土屋武, 坂本忠規, 六反 田千恵, 高野恵子: フエ・阮朝建築遺構群の細部意匠研究 7 ・ケオの形 状と彫刻について, ヴィエトナム/フエ・阮朝王宮の復原的研究, その 51 , 日本建築学会関東支部研究報告集 II , pp.525-528, 2002.3

7）坂本忠規, 中川武, 白井裕泰, 中沢信一郎, 土屋武: 阮朝漢喃史料にお ける建築の記述, ヴィエトナム/フエ・阮朝王宮の復原的研究, その 53 , 日本建築学会関東支部研究報告集 II , pp.533-536, 002.3

8）高野恵子：細部意匠研究による編年考察の可能性, ベトナム伝統住居の 体系的研究一所在調査と意匠技法の編年一総論第 5 章, 昭和女子大学国 際文化研究所紀要 7, pp.31-35, 2002.3

9）六反田千恵, 高野恵子, 齋藤潮美, 中川武, 中沢信一郎, 土屋武, 坂本 忠規, 白井裕泰 : フエ・阮朝建築遺構群の細部意匠研究 8 - 意匠形状に よる大梁 (ダウ・チェン) の分類, ヴィエトナム／フェ・阮朝王宮の復 原的研究, その 61 , 日本建築学会大会学術講演梗概集, F-2, pp.671-672, 2002.9

10）六反田千恵: 隆徳殿ドゥイ・ケオ彫刻絵様構成について, グエン朝・太廟・ 隆徳殿の修復計画, その 2 , 日本建築学会大会学術講演梗概集, F-2, pp.285-286, 2006.9

11）六反田千恵, 白井裕泰, 中川武: 両渦紋ドゥイ・ケオ彫刻の先端渦紋の分 類について, 阮朝・太廟・隆徳殿の修復計画, その 8 , 日本建築学会大 会学術講演梗概集，F-2, pp.183-184, 2007.9

12）六反田千恵, 白井裕泰, 中川武 : 両渦紋ドゥイ・ケオ彫刻の先端渦紋の分 類について 2 , 阮朝・太廟・隆徳殿の修復計画, その 14 , 日本建築学会 大会学術講演梗概集，F-2，pp.131-132，2008.9

13）六反田千恵, 白井裕泰, 中川武: 隆徳殿裳階部ケ才の彫刻絵様構成につ いて, 阮朝・太廟・隆徳殿の修復計画, その 20 , 日本建築学会大会学術 講演梗概集, F-2, pp.33-34, 2009.9

14）六反田千恵, 中川武, 林英昭, 木谷建太 : ドゥイ・ケオのプロポーション について, ヴィエトナム・フエ阮朝王宮の復原的研究, その 151 , 日本 建築学会関東支部研究報告集 II, pp.657-660, 2010.3

15）六反田千恵, 中川武, 林英昭, 木谷建太 : 勤正殿の前楹厅才・身舎大梁 ヴィ・ジャ・トゥの彫刻絵様について, ヴィエトナム・フエ阮朝王宮の 復原的研究, その 155 , 日本建築学会大会学術講演梗概集, F-2, pp.607-608, 2010.9

16）白井裕泰, 中川武：阮朝フエ王宮における隆徳殿の当初材について, 日 本建築学会計画系論文集, No.671, pp.149-155, 2012.1

17）六反田千恵, 中川武 : 勤正殿承雷部の彫刻絵様について, ヴィエトナム . フエ阮朝王宮の復原的研究, その 168 , 日本建築学会大会学術講演梗概 集, F-2, pp.469-470, 2012.9
18）六反田千恵, 中川武, 林英昭, 木谷建太 : 明命帝陵に関する史料記述比 較その 2 , ヴィエトナム・フエ阮朝王宮の復原的研究, その 173 , 日本 建築学会関東支部研究報告集 II , pp.745-748,2013.3

19) 六反田千恵, 中川武: 連棟型遺構「承榮」彫刻絵様分類, ヴィエトナム フエ阮朝王宮の復原的研究, その 177 , 日本建築学会大会学術講演梗概 集, F-2, pp.591-592, 2013.8

20）六反田千恵, 中川武：フエ阮朝建築遺構群における建築形式の分類，現 存遺構と『欽定大南會典事例』における記述の比較考察, 日本建築学会 計画系論文集，№.688，pp.1409-1414，2013.6

注

注 1）参考文献 16)によると、ものつくり大学が行った 2005-2010 年の解体 修理によって、隆徳殿は嘉隆 3 年 (1804)に創建され、明命 13 年 (1832) に屋根修理、成泰 12 年 (1900) に半解体修理が行われ、構造形式の 変更はないが、現遺構には当初材と後補材が混在していることが明ら かにされた。

注 2）参考文献 20)によると、興祖廟、延寿宮正殿、凝禧殿は規模を変更した 可能性が認められる。

注 3) 参考文献 2)参照。

注 4）富澤明は、『大南定録』、『欽定大南会典事例』、『大南一統志』から造営 に関連する記述を抽出し、『阮朝王宮及び皇帝陵の建築群の造営に関す る文献的研究』(早稲田大学修士論文、2011) にまとめた。さらに六反 田千恵は、『古都フエの建築』（ファン・トン・アン著、1992 年）およ びHMCC におけるヒアリングから造営に関連する事柄を抽出し、富澤 論文を加えて遺構ごとに整理し、『フエ・阮朝建築遺構群の細部意匠研 究』(早稲田大学博士論文, 私家版, 2014.2) にまとめた。

注 5）参考文献 1)-6）、9－15）、17）、19）参照。

注 6）鴻澤門・碑亭のドゥイ・ケオ彫刻絵様は、龍が変形しているが渦龍型 としている。

注 7）参考文献 2)参照。

注 8）五鳳楼のケオ意匠に特異性があるのは、7-1 で詳述したように、造営経 過の複雑さが反映しているのではないかと推察される。

注 9）参考文献 21)を参考に再構成した。

注 10）川嶋がケオ木鼻絵様の部位名称を「先端、中央、柱元、柱元下」とし たのは、部位を位置情報で表現したものであるが、獣形の部位として 「鼻先、顔、頭、顎」としたほうが、部位名称として相応しいと考え られる。

注 11）参考文献 10)参照。

注 12) 寿寧殿は、少なくとも建立当初の木鼻絵様を残している可能性がある。 注 13) 参考文献 8)参照。

注 14）「富樫洋之, 中川武，西本真一，中沢信一郎，白井裕泰，高野恵子, 土屋武, 石原彩子, 佐々木太清, 柳下敦彦: 興廟の構造形式と平面計 画における単位長, ヴィエトナム/フエ・阮朝王宮の復原的研究（そ の 10), 日本建築学会大会学術講演梗概集 F-2, pp.473-474, 1997.9」 を参照。

注 15）同慶帝陵の完成は、息子の啓定帝の時代とされ、後殿の建立年代はこ れより降る可能性がある。

注 16) 隆安殿（1908 年移築）、明徽閣（1902 年移築）、延寿宮長愉榭、嗣徳 帝陵鳴謙堂、同慶帝陵凝禧殿後殿・宮門（啓定帝期?）唯定帝期 （1916-25 年）以降に移築または大規模修理されたことが明らかにな れば、Dタイプは 20 世紀初期の絵様と考えることができる。

注 17) 図 7 は、六反田千恵『フエ・阮朝建築遺構群の細部意匠研究』(早稲田 大学博士論文, 2014.2) より転載した。

注 18) 獣形木鼻は「口」を持つが、繰形木鼻は「口」がなくなっている。

注 19）明徽閣は 1902 年に、隆安殿は 1908 年に移築されているので、両者の ドゥイ・ケオ木鼻は移築時のものである可能性がある。もしもそうであ るならば、繰形木鼻の初出は延寿宮長愉榭 (1848 年) ということになる。

注 20) - 22) 六反田千恵『フエ・阮朝建築遺構群の細部意匠研究』(早稲田大 学博士論文, 2014.2) 参照。

注 21）五鳳楼初層ドウイ・ケオ木鼻（タイプB）の絵様を図 8 に示す。

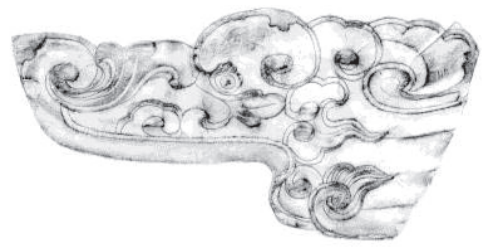

図8五鳳楼初層 ドゥイ・ケオ木鼻（タイプB） 


\title{
A STUDY ON THE DUOI KEO DESIGH OF WOODEN ARCHITECTURES IN THE NGUEN DYNASTY AT HUE
}

\author{
Hiroyasu SHIRAI*, Chie ROKUTANNDA** and Takeshi NAKAGAWA*** \\ * Prof., Dept. of Building Technologists, Faculty of Technologists, Institute of Technologists, Dr.Eng.
$* *$ Staff, Itsuko HASEGAWA Atelier, Dr.Arch. \\ *** Prof. emeritus, Waseda University, Director, Open Air Museum Meiji-Mura, Dr.Eng.
}

In order to clear the transition of design style, we have studied on the Duoi Keo design of wooden architectures in The Nguen Dynasty at Hue. The conclusion of this paper is as follows. : 1 . To clarify the production age of the Duoi Keo design of wooden architectures, we have cleared the creation age and detailed repair of 34 wooden architectures in existence by the document and hearing. 2. We have classified the Duoi Keo design of wooden architectures to four types, A type is “両渦文型”, B type is “龍頭吐水唐草文型”, C type is “小龍頭渦唐草文型 “, D type is “渦唐草文型”. 3. The transition of the Duoi Keo design is as follows. A-type $\rightarrow$ B-type $\rightarrow$ C-type and D-type. 4 . We have presumed the new construction age of the wooden architectures in existence, that is that Dien Tho Ninh was built in 1820, the upstairs of Ngo Mon was built in 1921-23, and Hung Mieu was built in the middle of 19 century. 